\title{
Rapid response petrology for the opening eruptive phase of the 2021 Cumbre Vieja eruption, La Palma, Canary Islands
}

\author{
Matthew J. Pankhurst ${ }^{\star \alpha}, \beta$, Jane H. Scarrow ${ }^{\gamma}$, Olivia A. Barbee ${ }^{\alpha}$, James Hickey $^{\delta}$, \\ Beverley C. Coldwell ${ }^{\alpha, \beta}$, Gavyn K. Rollinson ${ }^{\delta}$, José A. Rodríguez-Losada ${ }^{\alpha, \epsilon}$, \\ Alba Martín-Lorenzo ${ }^{\alpha}, \beta$, Fátima Rodríguez ${ }^{\alpha}$, William Hernández ${ }^{\alpha}$, David Calvo Fernández $^{\alpha}$, \\ Pedro A. Hernández ${ }^{\alpha, \beta}$, Nemesio M. Pérez ${ }^{\alpha, \beta}$ \\ $\alpha$ Instituto Volcanológico de Canarias (INVOLCAN), La Laguna, Santa Cruz de Tenerife, Spain. \\ $\beta$ Instituto Tecnológico y de Energías Renovables (ITER), Granadilla de Abona, Santa Cruz de Tenerife, Spain. \\ $\gamma$ Department of Mineralogy and Petrology, University of Granada, Campus Fuentenueva, 18071 Granada, Spain. \\ ${ }^{\delta}$ Camborne School of Mines, University of Exeter, Penryn Campus, Cornwall, TR10 9FE, United Kingdom. \\ ${ }^{\epsilon}$ Department of Animal Biology, Edaphology and Geology, Avenida Astrofísico Francisco Sánchez, s/n. \\ Facultad de Ciencias. Sección de Biología. 38200 La Laguna. Tenerife.
}

\begin{abstract}
How and why magmatic systems reactivate and evolve is a critical question for monitoring and hazard mitigation efforts during initial response and ongoing volcanic crisis management. Here we report the first integrated petrological results and interpretation provided to monitoring authorities during the ongoing eruption of Cumbre Vieja, La Palma, Canary Islands, Spain. The first eruptive products comprised simultaneous Strombolian fountain-fed lava flows and tephra fall from near-continuous eruption plumes. From combined field, petrographic and geochemical analyses conducted in the 10 days following sample collection, we infer low percentage mantle melts with a variably equilibrated multimineralic crystal-cargo and compositional fractionation by winnowing during eruptive processes. Hence 'rapid response' petrology can untangle complex magmatic and volcanic processes for this eruption, which combined with further study and methodological improvement can increasingly assist in active decision making.
\end{abstract}

\section{RESUMEN}

Este trabajo reporta los primeros resultados petrológicos integrados y su interpretación proporcionada a las autoridades para la monitorización volcánica del actual proceso eruptivo del volcán de Cumbre Vieja, La Palma. Los primeros materiales emitidos por esta erupción engloban coladas de lava, emitidas desde fuentes de lava de carácter estromboliano y caídas de piroclastos casi continuas desde plumas volcánicas. Gracias a observaciones de campo, análisis petrográfico y análisis geoquímico, interpretamos: una baja tasa de fusión del manto con una carga cristalina multimineral variablemente equilibrada además de fraccionamiento composicional debido a la dinámica del proceso eruptivo. Por lo tanto, la "rápida respuesta" petrológica se convierte en una herramienta fundamental para entender el proceso volcánico y magmático de esta erupción, el cual, combinado con estudios adicionales y la mejora de la metodología puede ayudar cada vez más en la toma activa de decisiones.

Keywords: Lava-tephra; Petrological monitoring; QEMSCAN; Mineral chemistry; Crystal cargo;

\section{INTRODUCTION}

Understanding the origins and evolution of the lithologically varied Canarian archipelago (Figure $1 \mathrm{~A}$ ) has long attracted international research efforts [e.g. Turner et al. 2015]. La Palma (Canary Islands, Spain) has experienced several magmatic episodes: Basal Complex ( 4.0-3.0 Ma); Garafia, Taburiente, Cumbre Nueva and Bejenado volcanoes ( 1.7-490 ka); and Cumbre Vieja ( 125 ka-present). It is the most active Canarian volcanic system in historical times, with eruptions in $~ 1480,1585,1646,1677,1712,1949,1971$ and 2021 [Hernandez-Pacheco and Valls 1982; Romero

*Corresponding author: mpankhurst@iter.es
Ruiz 1990; Global Volcanism Program 2013], indicating an inter-event period of between $\sim 230-20$ years. Previous historical eruptions along the Cumbre Vieja north-south trending rift zone have been characterized by the appearance of multiple vents aligned obliquely to the rift zone axis. Eruptive activity has typically been explosive at the summit vent(s) and effusive at the base and flanks of the volcanoes, with lavas having a variably alkali enriched basaltic composition [Klügel et al. 1999; White and Schmincke 1999; Carracedo et al. 2001; Klügel et al. 2017].

On 19 September 2021, Cumbre Vieja volcano (Figure 1A) erupted after 50 years of quiescence. Prior to the ongoing activity, ten seismic swarms at 2-30 km 

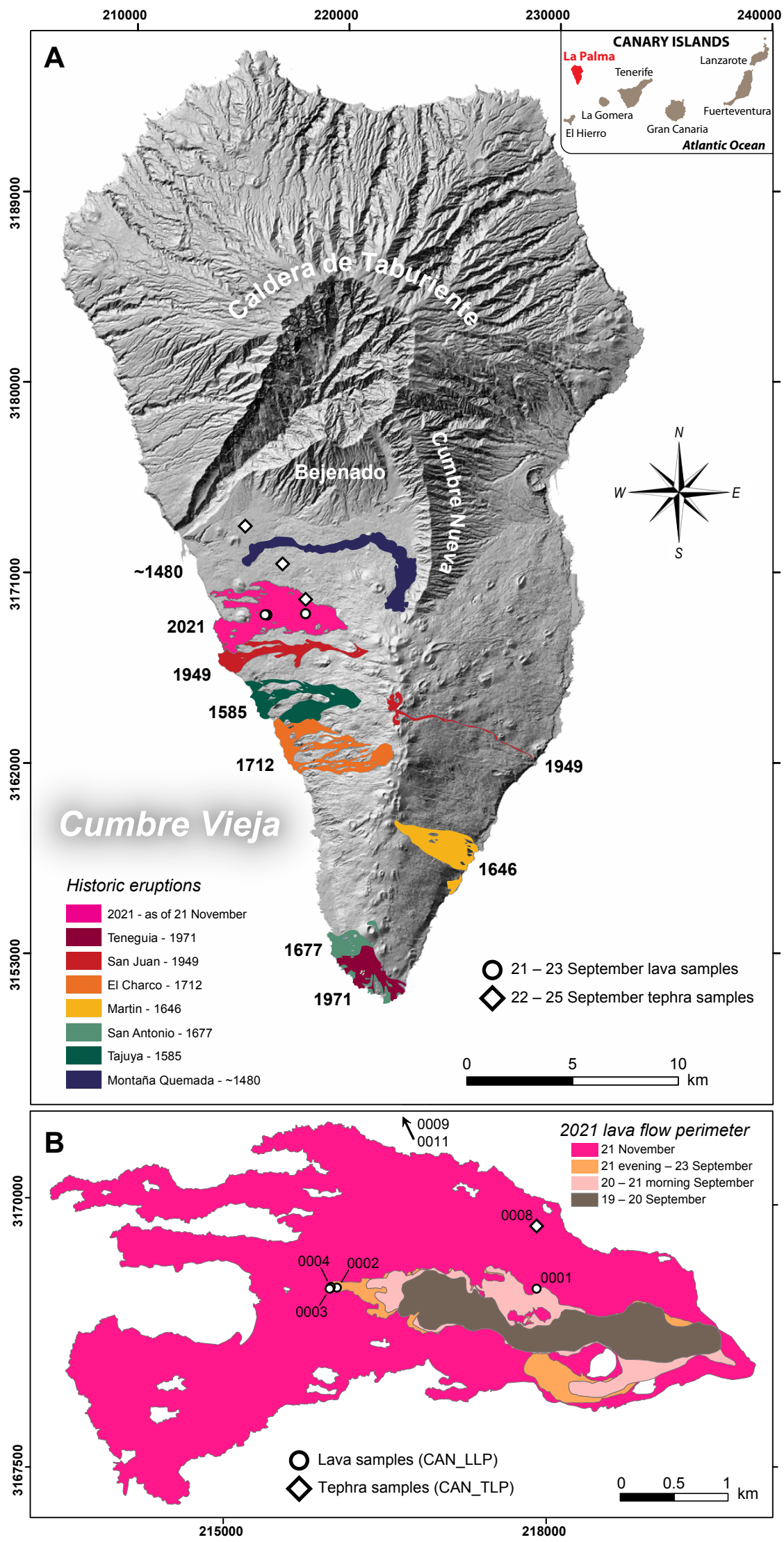

Figure 1: [A] Locations of lava and tephra samples and historic eruptions [Hernandez-Pacheco and Valls 1982; Romero Ruiz 1990; Global Volcanism Program 2013]; [B] selected flow extent snapshots and sample locations. 
depth had been recorded in La Palma since 2017. On 11 September 2021, a seismic swarm interpreted to be related to magma intrusion was detected at $8-13 \mathrm{~km}$ depth by Instituto Volcanológico de Canarias (INVOLCAN) and the Instituto Geográfico Nacional (IGN) [Global Volcanism Program 2021a]. In the following 6 days, until 17 September, earthquakes increased in intensity to a maximum of Ml 3.4, with hypocenters shallowing to $8-10 \mathrm{~km}$ and migrating slightly westward; over the same period, the maximum ground deformation amounted more than $20 \mathrm{~cm}$ [Global Volcanism Program 2021a]. After a short lull (17-18 September) seismicity increased early on 19 September at depths of 0 $6 \mathrm{~km}$ with earthquakes up to Ml 4.2 coincident with an increase in vertical deformation. The eruption began at 14.02 GMT at Cabeza de Vaca, in the municipality of El Paso, 2 km north-west of the 1949 San Juan eruptive foci (Figure 1A). The initial explosive activity coincided with volcanic tremor, ejection of lava from a $200 \mathrm{~m}$-long fissure and a plume composed of both $\mathrm{SO}_{2}{ }^{-}$ rich gas ( $3 \mathrm{~km}$ high) and ash (1.5 km high). Cone building initiated around the main fissure vent, which soon resolved into emission centers dominated either by an ash plume or lava fountains. The latter fed flows that coursed to the west and west-southwest [Global Volcanism Program 2021b].

\section{Motivations}

Petrology remains an underutilized science during volcanic crises despite its potential and unique contribution to monitoring and forecasting efforts, and by extension, to decision makers. Measurements of volcanic products include: textures, mineralogy, mineral chemistry (and profiles), whole-rock geochemistry, volatiles, isotope geochemistry, and rheology [e.g. Blundy and Cashman 2008; Cashman and Sparks 2013; Jerram et al. 2018; Re et al. 2021]. Petrology combines these data into interpretations of the magmatic system state and evolution, which can inform understanding of the dynamic processes driving eruptions and physical behaviours of tephra and lava. Hence, forecasts of volcanic behaviour underpinned by petrological characterization and trends are more robust. Notably, in several volcano observatories worldwide petrology is utilized to obtain fundamental observations of hand specimens, thin sections, whole-rock geochemistry, and more rarely, mineral chemistry [Re et al. 2021]. Conducting petrological study to its highest potential during volcanic eruptions is hampered by inherent challenges: 1) the necessity to physically access volcanic products; 2) ensuring that representative samples are selected for future, more detailed study; and 3) generating data that are insightful on reporting timescales that are useful. Further, conventional petrographic analysis is slow, so it is understandable that expectations for timely input can be low. This general sce- nario leaves petrology easily underutilized in favor of vastly more immediate and unquestionably useful data streams from geophysical and gas geochemical monitoring techniques. However, with the advent of rapid petrological analytical techniques such as automated mineralogy and micro-CT scanning [e.g. Pankhurst et al. 2014; Guntoro et al. 2019; Hornby et al. 2019], petrology has clear potential to be faster and thus more useful during a volcanic crisis.

It is well understood within the volcanological community that eruptions from quiescent volcanic systems pose an increasing risk to human populations and infrastructure at a global scale. As such, petrological understanding is of paramount importance because in the majority of such volcanic centers there is no record of volcanic behaviour other than the rocks themselves; petrology is uniquely able to compare data from a new eruption with an empirical record of the past. Petrological laboratories that host suites of high-end instrumentation and human resource support are far rarer than hazardous volcanic settings and are not commonly situated close to eruptive centers or zones. How to conduct 'responsive petrology' efficiently and effectively in the event of an eruption is, therefore, a pressing question that needs attention. Determining the potential value of advanced petrology in these scenarios is also critical due to a current lack of demonstrated impact.

Our motivation to conduct an integrated mineral chemistry and textural study is twofold: to undertake a live exercise in mobilizing a petrology base to a volcanic centre; and to produce insightful data (i.e. beyond that which standard whole-rock and petrographic analysis can provide) for inclusion into the monitoring, forecasting and decision-making efforts. This report focusses upon the latter to communicate the petrological observations and interpretations to the wider community in a timely manner (preprint link ${ }^{*}$ ). A more extensive and reflective contribution on the former is planned for publication in the near future.

\section{RAPID RESPONSE PETROLOGICAL METHODOL- OGY}

Samples analyzed here were collected during the first week of activity from initial lava flow (CAN_LLP_0001, $2,3,4)$ and tephra fall (chronologically, increasing in distance from the vent: CAN_TLP_0008, 9, 11) (Figure 1B) (sample locations and full datasets are available at Research Square ${ }^{*}$.

Here we present the following datasets for the very earliest effusive lavas and explosive tephras of the 2021 La Palma volcanic eruption: X-ray diffraction (XRD); petrographic analysis; quantitative evaluation of minerals by scanning electron microscope (QEMSCAN $\left.{ }^{\circledR}\right)$; electron microprobe (EPMA); and whole-rock major (X-ray fluorescence, XRF) and trace element (inductively cou-

\footnotetext{
* https://doi.org/10.21203/rs.3.rs-963593/v1
} 


\section{Sample collection}
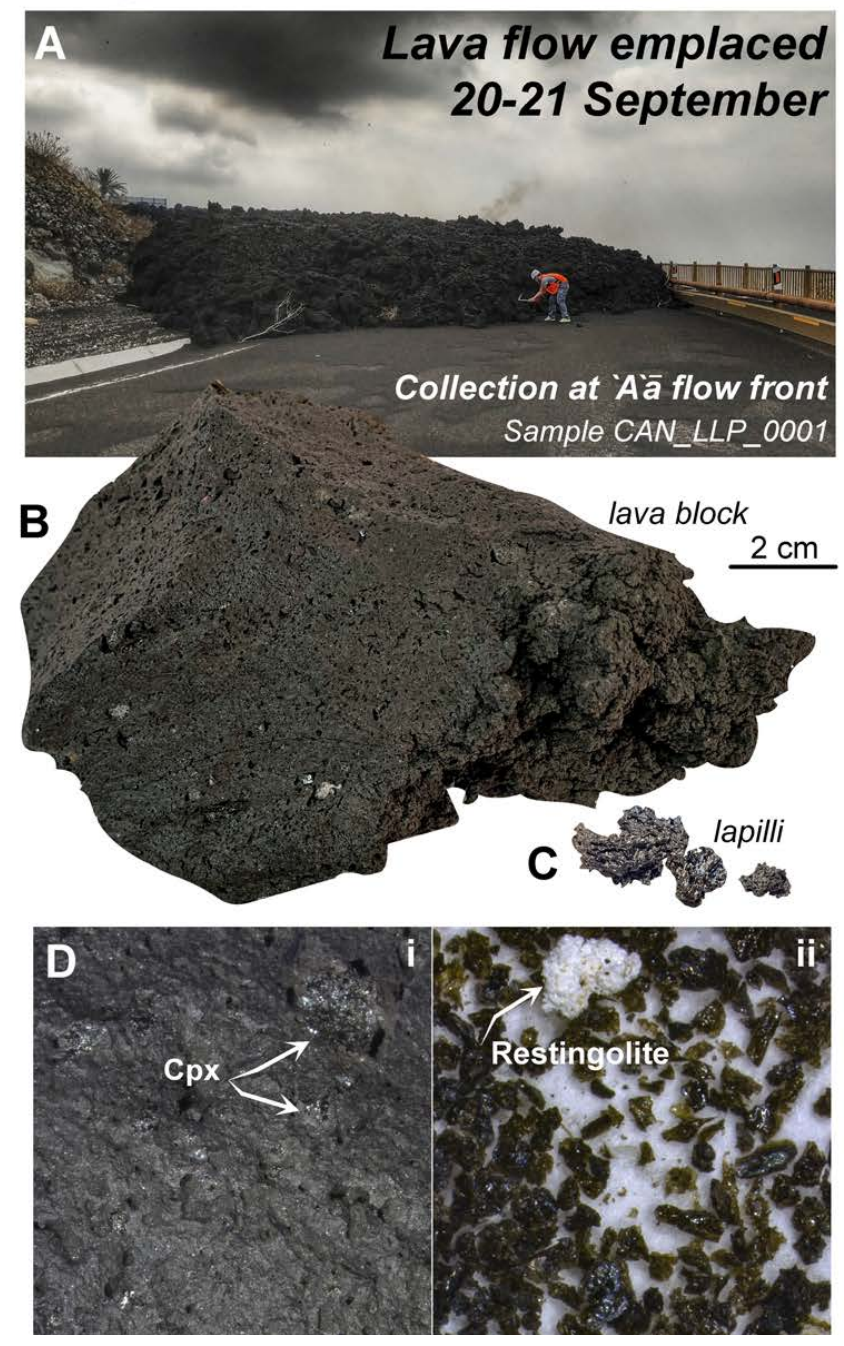

Figure 2: Field photograph and hand specimens: [A] CAN_LLP_0001 lava collection at flow front [B] CAN_LLP_0001 hand specimen; [C] CAN_TLP_0001 coarse particles hand specimen; [D] (i) CAN_LLP_0001 stereomicroscope image, (ii) CAN_TLP_0011 stereomicroscope image including ultra-rare restingolite (pending confirmation).

pled mass spectrometry, ICP-MS) geochemistry. Petrographic thin sections were made at the University of La Laguna, Tenerife, Spain and the Department of Mineralogy and Petrology, University of Granada, Spain.

Suitable sampling points were identified with a thermal camera. Lava samples were collected from active flow fronts either warm (CAN_LLP_0001), or for all other samples, hot incandescent and immediately water quenched. Tephra was collected from direct fall deposits. Each sample was viewed using a ZEISS Discovery V20 stereomicroscope for initial assessment on La Palma.

Whole-rock and mineral chemical analyses were performed at the University of Granada Department of Mineralogy and Petrology and Scientific Instrumenta- tion Centre. All samples were powdered in an automatic agate mortar and pestle grinder. Whole-rock Xray diffraction (XRD) of the milled samples was performed using a PANalytical X'Pert Pro diffractometer ( $\mathrm{CuK} \alpha$ radiation, $45 \mathrm{kV}, 40 \mathrm{~mA}$ ) equipped with an $\mathrm{X}^{\prime}$ Celerator solid-state linear detector, using a step increment of $0.008^{\circ} 2 \theta$ and a total counting time of $10 \mathrm{~s}$ per step. Data were processed using HighScore software to identify key mineral peaks, d spacing Å: clinopyroxene 2.55-2.99; plagioclase 3.19-3.21; amphibole 8.358.44. Whole-rock major element determinations were performed by XRF after fusion with lithium tetraborate. Typical precision was better than $\pm 1.5 \%$ for an analyte concentration of $10 \mathrm{wt}$. \%. Zirconium was determined by XRF on glass beads with a precision better than $\pm 4 \%$ for 100 ppm Zr. Whole-rock trace element determinations were done by ICP-MS after $\mathrm{HNO}_{3}+\mathrm{HF}$ digestion of $0.1000 \mathrm{~g}$ of sample powder in a Teflonlined vessel at $\sim 180^{\circ} \mathrm{C}$ and 200 psi for $30 \mathrm{~min}$, evaporation to dryness and subsequent dissolution in $100 \mathrm{ml}$ of 4 vol. $\% \mathrm{HNO}_{3}$. Instrument measurements were carried out in triplicate with a PE SCIEX ELAN-5000 spectrometer using rhodium as an internal standard. Precision, as determined from standards WSE, BR, and AGV run as unknowns, was better than $\pm 2 \%$ and $\pm 5 \%$ for analyte concentrations of 50 and 5 ppm, respectively. Major element analyses of minerals were obtained by wavelength dispersive analyses with a Cameca SX-100 electron microprobe (EPMA), using mainly synthetic standards. Accelerating voltage was $20 \mathrm{kV}$ and beam current was $20 \mathrm{nA}$. Spot size was 5 microns.

Automated mineralogy was undertaken at the Camborne School of Mines Chemical, Imaging and Mineralogical Facility, University of Exeter, U.K. Sample CAN_LLP_0001 was mounted in a $30 \mathrm{~mm} \mathrm{di-}$ ameter epoxy resin block, polished to a 1 micron finish, carbon-coated to $25 \mathrm{~nm}$, then analyzed by a QEMSCAN ${ }^{\circledR} 4300$ [Gottlieb et al. 2000]. Sample measurement and data processing used iMeasure v4.2SR1 and iDiscover 4.2SR1 and 4.3 [Rollinson et al. 2011]. The QEMSCAN ${ }^{\circledR}$ settings used $25 \mathrm{kV}, 5 \mathrm{nA}$, a 1000 X-ray count rate per pixel, a WD of around $22 \mathrm{~mm}$ under high vacuum and beam calibration every 30 minutes. Sample measurement used the fieldscan measurement mode [Pirrie and Rollinson 2011] to analyze the samples at an $\mathrm{X}$-ray resolution/pixel spacing of $5 \mu \mathrm{m}$ and a $1000 \mu \mathrm{m}^{2}$ field size ( $\times 68$ magnification).

\section{Results}

We undertook petrological monitoring of the Cumbre Vieja eruption via a series of micro-analytical and whole-rock petrological analyses of juvenile scoria, ash and lava. This approach can be used to provide insight into volcanic plumbing systems as they assemble before, and evolve throughout, eruption [e.g. Kahl et al. 2015; Pankhurst et al. 2018]. 


\section{Petrographic analysis}

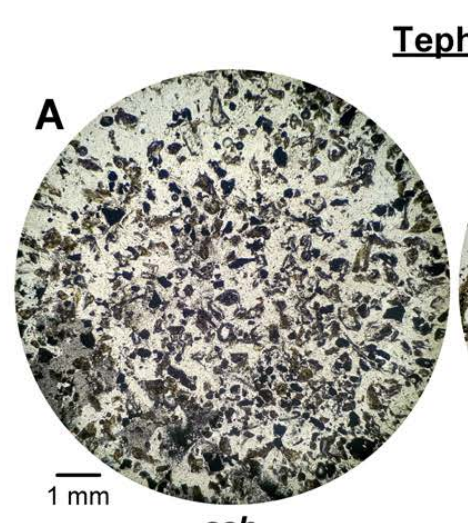

ash

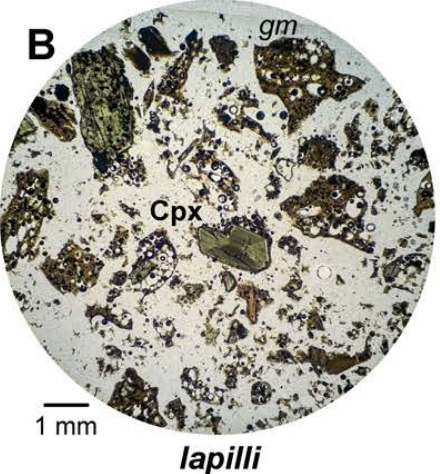

Iapilli

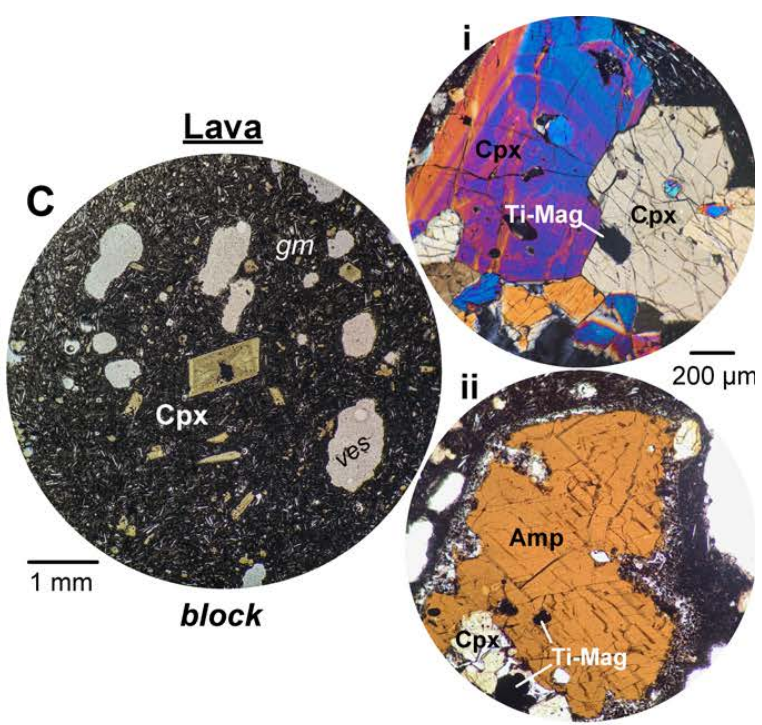

Figure 3: Photomicrographs of $[\mathrm{A}]$ ash; $[\mathrm{B}]$ lapilli and [C] lava (i) possible xenoliths with $120^{\circ}$ grain boundaries (ii) amphibole with distinct reaction rim. Abbreviations: $\mathrm{Cpx}=$ clinopyroxene; $\mathrm{Amp}=$ amphibole, Ti-mag = titanomagnetite; gm = groundmass; Ves = vesicles .

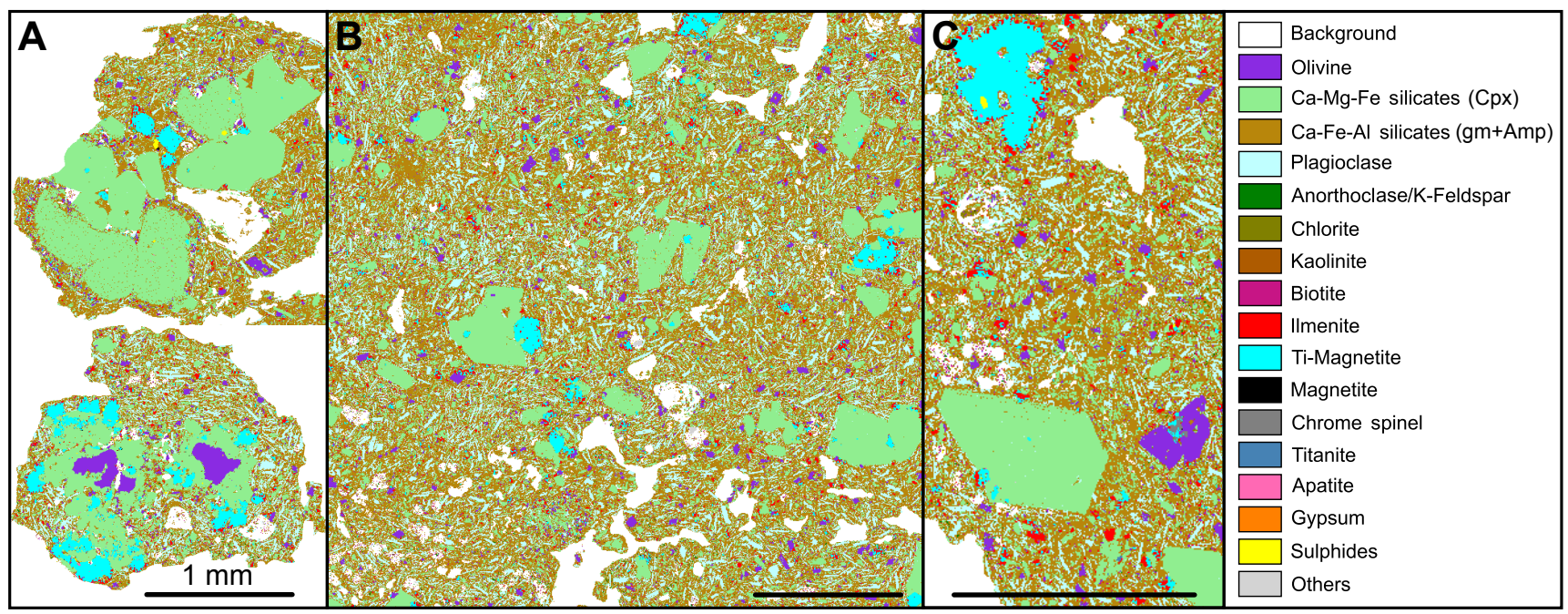

Figure 4: Lava CAN_LLP_0001 QEMSCAN® maps illustrate and quantify crystal clusters with variable textures and mineralogy $[\mathrm{A}]$ lava fragments containing crystal clusters with different textures and mineralogy, composed primarily of clinopyroxene \pm Ti-magnetite \pm olivine; [B] representative textures of vesicular porphyritic lava; [C] an area exemplifying contrasted morphologies between typical crystals of clinopyroxene, Ti-magnetite and olivine. Abbreviations: $\mathrm{Cpx}=$ clinopyroxene; $\mathrm{Amp}=$ amphibole, Ti-mag = titanomagnetite; $\mathrm{gm}=$ groundmass.

\subsection{Petrology}

Juvenile lavas and tephra erupted during the ongoing activity contain coarse crystals of clinopyroxene, olivine and amphibole, identifiable by hand-lens, that can provide a rapid real-time guide to system evolution (Figure 2). The multimineralic cargo observed (Figure 3) raises the potential to extract detailed system information and serves as a baseline to track any trends that may be used to help forecast changes in eruptive behaviour and evolving hazards. XRD anal- ysis of all four lava samples (CAN_LLP_0001, 2, 3, 4) confirmed hand specimen identification of clinopyroxene, olivine and amphibole major mineral phases, with feldspathoids being notably absent. Following this, thin section study of a sample from the 20 September flow front (CAN_LLP_0001, Figure 2A) showed it to be hypocrystalline and porphyritic with $\sim 15$ modal $\%$ vesicularity (Figure 3C). Clinopyroxene is the most common coarse mineral (1-3 mm diameter, 15-20 modal \%) and is present as euhedral-subhedral solitary crystals or in mono- and polymineralic (clinopyroxene, 

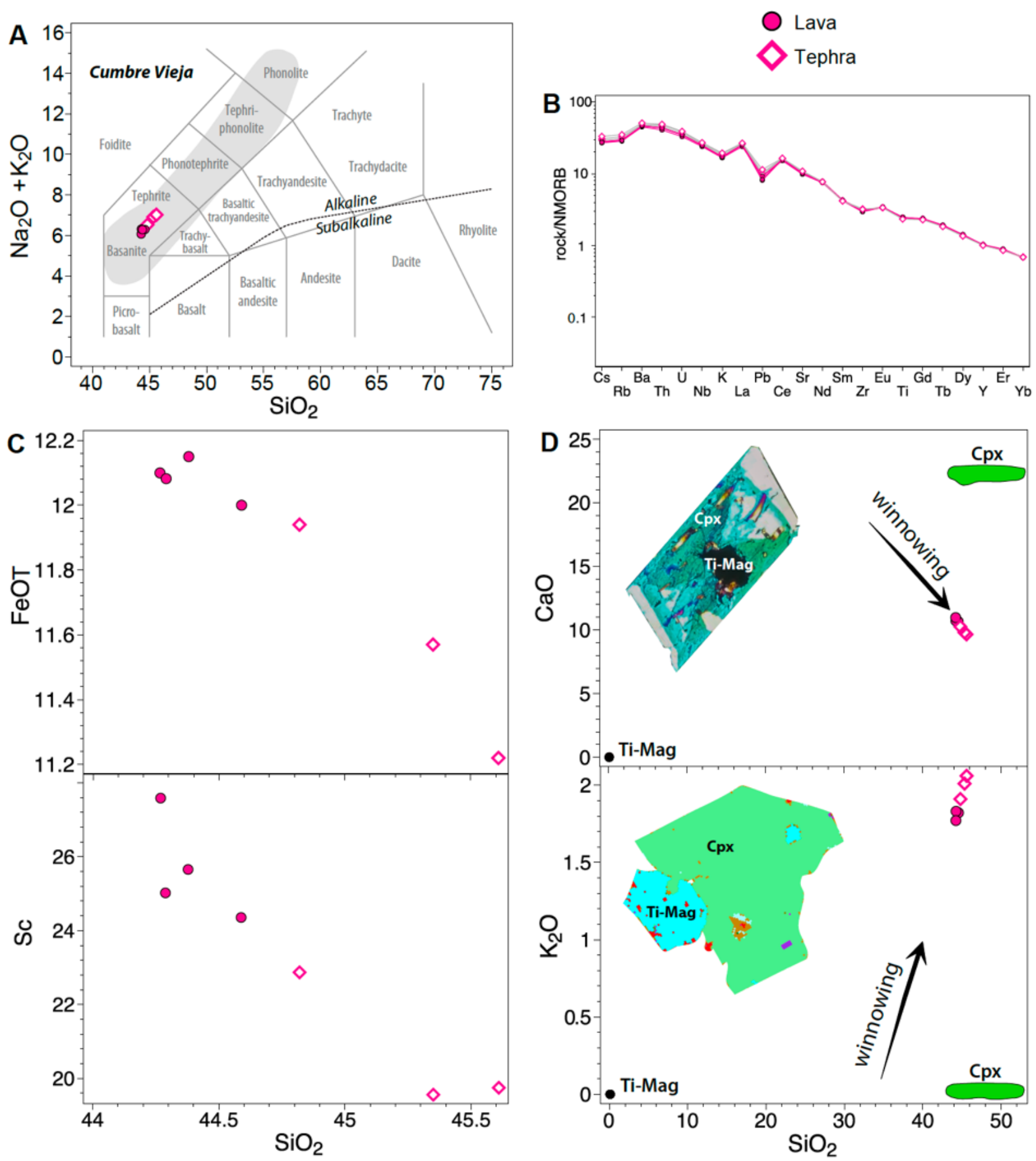

Figure 5: [A] TAS sample classification and historic Cumbre Vieja eruptions [Klügel et al. 2017]; [B] NMORBnormalized [Hofmann 1988] whole-rock diagram; [C] $\mathrm{FeO}$ and Sc vs $\mathrm{SiO}_{2}$ diagrams indicate clinopyroxene winnowing; refined by [D] $\mathrm{CaO}$ and $\mathrm{K}_{2} \mathrm{O}$ vs $\mathrm{SiO}_{2}$ to include Ti-magnetite and confirmed by petrographic observations $\sim 85: 15$ clinopyroxene:Ti-magnetite ratio (insets).

Fe-Ti oxides \pm olivine \pm amphibole) clusters (up to $7 \mathrm{~mm}$ ), including possible xenoliths with $120^{\circ}$ grain boundaries (Figure 3Ci). Clinopyroxene commonly displays concentric and sector zoning, with some embayments and abundant Fe-Ti oxides and apatite inclusions; sieve-textures are rare. Amphibole crystals $(\sim 4$ modal $\%)$ are anhedral-subhedral, $0.5-2.5 \mathrm{~mm}$ across and have distinct reaction rims (Figure 3Cii).
Olivine ( 1 modal \%) usually forms euhedral-anhedral isolated crystals that are $\sim 0.5-1.5 \mathrm{~mm}$. Fe-Ti oxides ( 1 modal \%) are subhedral-anhedral and 0.5$1 \mathrm{~mm}$. Groundmass minerals include abundant plagioclase, Fe-Ti oxides, clinopyroxene and olivine. All the tephra samples, CAN_TLP_0008, 9, 11, are mineralogically comparable to the lava but with a fragmented, hypocrystalline texture (Figure 3). Notably, the sam- 
ple collected on 25 September (CAN_TLP_0011) associated with a particularly explosive phase of activity, contain flecks of white pumitic material, comparable in aspect to restingolite from the 2011 El Hierro submarine eruption [cf. Rodriguez-Losada et al. 2015].

In our QEMSCAN ${ }^{\circledR}$ analysis we examined a $27 \mathrm{~mm}^{2}$ area of CAN_LLP_0001 representing 8 M points measured in $<17 \mathrm{hr}$ with a $5 \mu \mathrm{m}$ pixel size. The results highlight three dominant mineral groups accounting for $90.07 \%$ modal mineralogy (Figure 4): Ca-Fe-Al silicates (49.54 modal \%) and Ca-Mg-Fe silicates (20.94 modal \%), interpreted to be groundmass+amphibole and clinopyroxene, respectively, and plagioclase (19.59 modal \%). The next most abundant minerals are olivine $(2.70$ modal \%), Ti-Magnetite (2.12 modal \%), ilmenite (1.95 modal \%) and biotite (1.65 modal \%). Plagioclase is present as groundmass crystal laths, whereas olivine, Ti-magnetite and ilmenite are present as both equant and microlitic crystals. Groundmass with textures finer than excitation volume contributes to total $\mathrm{Ca}-\mathrm{Mg}-\mathrm{Fe}$ silicates, hence the elevated value with respect to petrographic analysis.

\subsection{Mineral chemistry}

Electron microprobe analysis confirms clinopyroxene as titanaugite and demonstrates no clear major element difference between cores of euhedral grains, corroded crystals and monomineralic clusters. Rims, however, are generally richer in $\mathrm{SiO}_{2}$ and $\mathrm{MgO}$, and poorer in $\mathrm{TiO}_{2}, \mathrm{Al}_{2} \mathrm{O}_{3}$ and $\mathrm{Na}_{2} \mathrm{O}$. Large olivine grains have uniform compositions, $\mathrm{Fo}_{78-80}$, $\mathrm{Cr}$-spinel is present as inclusions. Ti-magnetite $\left(3-5 \mathrm{wt} \% \mathrm{TiO}_{2}\right)$ is present both as discrete grains and in the groundmass with slightly higher Ti concentration. Amphibole is kaersutite [Leake et al. 1997]; no core-rim zoning was detected. Groundmass plagioclase ranges between $\mathrm{An}_{58-67}$, with the exception of two two grains found to have considerably higher $\mathrm{Na}\left(\mathrm{An}_{32-43}\right)$.

\subsection{Whole-rock geochemistry}

Whole-rock XRF and ICP-MS analyses show products have restricted, primitive, metaluminous, alkaline whole-rock compositions (Figure 5A-D); lava collected on 21-23 September $\left(\mathrm{SiO}_{2} 44.27-44.59 \mathrm{wt} \%\right)$ is slightly more primitive than tephra collected on 19-25 September (44.82-45.61 wt \%). Normalized to NMORB, all analyzed samples show positive $\mathrm{Ba}, \mathrm{Th}, \mathrm{U}, \mathrm{La}, \mathrm{Ce}$, and $\mathrm{Eu}$ anomalies (Figure 5B). Chondrite-normalized values show LREE are enriched relative to $\operatorname{HREE}\left(\mathrm{La}_{\mathrm{N}} / \mathrm{Yb}_{\mathrm{N}}\right.$ 23.9-26.5), Eu anomalies are absent. All rocks have 15.5-16\% normative nepheline. In both tephra and lava, $\mathrm{Al}_{2} \mathrm{O}_{3}, \mathrm{Na}_{2} \mathrm{O}$ and $\mathrm{K}_{2} \mathrm{O}$, $\mathrm{Zr}$ plus large ion lithophile elements correlate positively with $\mathrm{SiO}_{2}$, whereas $\mathrm{FeOT}$, $\mathrm{MgO}, \mathrm{CaO}$ and $\mathrm{TiO}_{2}$ plus Sc and $\mathrm{V}$ correlate negatively (Figure 5C-D).

\section{Discussion}

Geochemically, eruptive products plot as basanitetephrites (Figure 5A), yet mineralogical observations, based predominantly on the absence of feldspathoids, lead to their classification as alkali basalts [Le Maitre et al. 2005], implying a comparatively higher degree of mantle melting [McKenzie and Bickle 1988]. Petrography and mineral chemistry illustrate a complex crystal cargo. In addition to euhedral clinopyroxene phenocrysts, rare variably resorbed clinopyroxene is observed. Anhedral olivine is recognized both in ripenedskeletal and also rounded-embayed forms. Amphibole has marked reaction rims and a variably oxidized appearance (Figure 3Ci). We suggest the current eruption is tapping melt-mush magma mingling zones.

Major and trace element trends, together with petrographic observations, indicate limited clinopyroxene ( $>85 \%)$ and titanomagnetite $(\sim 15 \%)$ fractionation, interpreted as winnowing between lava and tephra with increasing distance from the vent (Figure 3 and Figure 5A-D) [Cas and Wright 1988]. Convective circulation and turbulence in the gas and ash plume can carry fine glassy material into the upper eruptive column, and as a result, downwind. Crystals and lithics concentrate in the main eruptive column and fall-out close to the vent, resulting in a fractionation pattern not observed in the lava.

Monitoring teams are sampling fresh deposits of tephra and lava with a regularity modulated by accessibility (currently daily), thus preserving a collection of samples which in many locations have subsequently been buried beneath later eruptive products. Olivine abundance is being keenly tracked in collected samples, and at the time of writing appears to be rising, coincident with overall lava production. We suggest two possible end-member interpretations, as defined by the origins of participating magmas. Earliest eruption products could represent older, reactivated magma from a comparatively shallow reservoir that is being depleted as newer magma from deeper in the system arrives at the vent and now solely drives the eruption. Alternatively, all volcanic products are derived from the same parental magma that traversed colder crust in stages for $\sim 1$ week, triggering the recorded seismic unrest prior to eruption, and involving reactive flow [Jackson et al. 2018], gas charging, crystallization, and incorporation of country rock lithologies. Having now warmed the country rock, parental magma can ascend more efficiently. Elements of each end-member interpretation are plausible in a hybrid model. These alternatives will be tested by continued petrological eruption tracking and further analysis. 
6 Conclusions For RAPID PETROLOGICAL MONITORING OF ERUPTING VOLCANOES

1. Automated and rapid mineral chemistry analysis, here by QEMSCAN ${ }^{\circledR}$, has been shown to form a robust bridge between more conventional near-realtime petrological analysis techniques of thin section petrography (mineralogy, texture) and wholerock analysis (mineralogy, geochemistry).

2. Targeted in-situ mineral chemistry analysis was made more efficient with the benefit of the rapid characterization and is also shown to have complementary value.

3. Bulk chemical trends together with textural and mineralogical observations have been made within a few weeks of the samples' eruption, including sample transit and data processing, which both have potential for streamlining. It is plausible, therefore, that detailed and insightful petrological input can be delivered on a timescale that is useful for initial response and ongoing volcanic crisis management. We suggest that state-of-the-art petrology is now more time-limited by logistical elements than those inherent in its practice.

4. Here specifically, the crystal cargo observed describes a multi-component magmatic system which complements and influences the broad geophysical understanding of the volcanic activity. The variety of magmatic interactions illustrated by complex mineral textures point to a range of plausible sources for volcanic gas and helps contextualize observations of abundant $\mathrm{SO}_{2}$, especially in the opening phase of this eruption.

5. The first eruptive volcanic products studied here provide an initial benchmark for understanding and forecasting the rheological evolution of the lava flows being observed in real time, as well as for the evolution of the eruption. As such, they help inform planning in the context of potential areas and rates of lava inundation.

\section{Acknowledgements}

Antonio Alvarez, Jaime Martin and Adrian Jones are thanked for field support and loan of equipment. Comunidad de Regantes Dos Pinos are thanked for hosting the petrology base. JHS thanks laboratory staff and colleagues at the UGR for helping expedite production of results. Josh Hayes is thanked for editorial handling and comments that improved the manuscript. We are much obliged to reviewers Fabian Wadsworth and Geoff Kilgour for the time and effort they took to help us improve the clarity and rigour of our interpretations. The work was funded in part by VOLRISKMAC II (MAC2/3.5b/328) co-financed by the EC
Cooperation Transnational Program MAC 2014-2020, and TFASSISTANCE, co-financed by the 2016-2025 Insular Development Strategic Framework (MEDI) of the Tenerife Island Council and by the Canary Islands Development Fund (FDCAN) of the Canary Islands Government.

\section{Author CONTRibutions}

M.J.P. initiated the study, contributed to writing the manuscript, collected samples. J.H.S. contributed to writing the manuscript, prepared figures, collected samples. O.A.B. contributed to writing the manuscript, prepared figures. J.H. contributed to writing the manuscript. B.C.C. initiated the study, contributed to writing the manuscript, collected samples. G.R. contributed to writing the manuscript and processed samples. J.A.R.L. contributed to writing the manuscript. A.M.L. conducted fieldwork and processed samples. F.G.R. conducted fieldwork and processed samples. W.H. undertook the cartography. D.C.F. conducted fieldwork and contributed to writing the manuscript. P.H. conducted fieldwork and processed samples. N.P. initiated the study.

\section{Data availability}

Full datasets are available at Research Square: https: //assets.researchsquare.com/files/rs-963593/ v1/9f174d00-262e-4f21-b0d2-6825cf131538.pdf?c= 1634295351 (DOI: 10.21203/rs.3.rs-963593/v1).

\section{COPYRight NOTICE}

(c) The Author(s) 2022. This article is distributed under the terms of the Creative Commons Attribution 4.0 International License, which permits unrestricted use, distribution, and reproduction in any medium, provided you give appropriate credit to the original author(s) and the source, provide a link to the Creative Commons license, and indicate if changes were made.

\section{REFERENCES}

Blundy, J. and K. Cashman (2008). "Petrologic Reconstruction of Magmatic System Variables and Processes". Minerals, Inclusions And Volcanic Processes. Ed. by K. D. Putirka and F. J. Tepley III. Vol. 69. 1. Mineralogical Society of America, pp. 179-239. Dor: 10.2138/rmg. 2008.69.6.

Carracedo, J., E. Rodríguez Badiola, H. Guillou, J. de la Nuez, and F. J. Pérez Torrado (2001). "Geology and volcanology of La Palma and El Hierro, Western Canaries". Estudios Geológicos 57, pp. 175-273. 
Cas, R. A. F. and J. V. Wright (1988). Volcanic Successions Modern and Ancient. Springer Netherlands. Dor: 10 . 1007/978-94-009-3167-1.

Cashman, K. V. and R. S. J. Sparks (2013). "How volcanoes work: A 25 year perspective". Geological Society of America Bulletin 125(5-6), pp. 664-690. IssN: 19432674. Dor: $10.1130 / \mathrm{b} 30720.1$.

Global Volcanism Program (2013). "Volcanoes of the World, v. 4.10.3". Ed. by E. Venzke. Smithsonian Institution. Dor: 10.5479/si.GVP. VOTW4-2013. [online].

- (2021a). "Report on La Palma (Spain)". Weekly Volcanic Activity Report, 8 September-14 September 2021. Ed. by S. K. Sennert. Smithsonian Institution and US Geological Survey. [online].

- (2021b). "Report on La Palma (Spain)". Weekly Volcanic Activity Report, 15 September-21 September 2021. Ed. by S. K. Sennert. Smithsonian Institution and US Geological Survey. [online].

Gottlieb, P., G. Wilkie, D. Sutherland, E. Ho-Tun, S. Suthers, K. Perera, B. Jenkins, S. Spencer, A. Butcher, and J. Rayner (2000). "Using quantitative electron microscopy for process mineralogy applications". The Journal of The Minerals, Metals E Materials Society 52(4), pp. 24-25. ISSN: 1543-1851. DoI: $10.1007 /$ s11837-000-0126-9.

Guntoro, P. I., G. Tiu, Y. Ghorbani, C. Lund, and J. Rosenkranz (2019). "Application of machine learning techniques in mineral phase segmentation for Xray microcomputed tomography $(\mu \mathrm{CT})$ data". Minerals Engineering 142, p. 105882. ISSN: 0892-6875. DOI: 10.1016/j.mineng. 2019.105882.

Hernandez-Pacheco, A. and M. Valls (1982). "The historic eruptions of La Palma island (Canaries)". Arquipélago. Série Ciências da Natureza 3, pp. 83-94.

Hofmann, A. W. (1988). "Chemical differentiation of the Earth: the relationship between mantle, continental crust, and oceanic crust". Earth and Planetary Science Letters 90(3), pp. 297-314. DoI: 10.1016/0012$821 \mathrm{x}(88) 90132-\mathrm{x}$.

Hornby, A. J., Y. Lavallée, J. E. Kendrick, G. Rollinson, A. R. Butcher, S. Clesham, U. Kueppers, C. Cimarelli, and G. Chigna (2019). "Phase partitioning during fragmentation revealed by QEMSCAN Particle Mineralogical Analysis of volcanic ash". Scientific Reports 9(1). ISSN: 2045-2322. DOI: 10.1038 / s41598-01836857-4.

Jackson, M. D., J. Blundy, and R. S. J. Sparks (2018). "Chemical differentiation, cold storage and remobilization of magma in the Earth's crust". Nature 564(7736), pp. 405-409. ISSN: 1476-4687. DOI: 10 . 1038/s41586-018-0746-2.

Jerram, D. A., K. J. Dobson, D. J. Morgan, and M. J. Pankhurst (2018). "The Petrogenesis of Magmatic Systems: Using Igneous Textures to Understand Magmatic Processes". Volcanic and Igneous Plumbing Systems. Ed. by S. Burchardt. Elsevier, pp. 191-229. Dor: 10.1016/b978-0-12-809749-6.00008-x.
Kahl, M., S. Chakraborty, M. Pompilio, and F. Costa (2015). "Constraints on the Nature and Evolution of the Magma Plumbing System of Mt. Etna Volcano (1991-2008) from a Combined Thermodynamic and Kinetic Modelling of the Compositional Record of Minerals". Journal of Petrology 56(10), pp. 20252068. ISSN: 1460-2415. DOI: 10.1093 / petrology / egv063.

Klügel, A., H. Schmincke, J. D. L. White, and K. A. Hoernle (1999). "Chronology and volcanology of the 1949 multi-vent rift-zone eruption on La Palma (Canary Islands)". Journal of Volcanology and Geothermal Research 94(1-4), pp. 267-282. DoI: $10.1016 / \mathrm{s} 0377-$ 0273 (99) $00107-9$.

Klügel, A., K. Galipp, K. Hoernle, F. Hauff, and S. Groom (2017). "Geochemical and Volcanological Evolution of La Palma, Canary Islands". Journal of Petrology 58(6), pp. 1227-1248. IssN: 1460-2415. DOI: $10.1093 /$ petrology/egx052.

Le Maitre, R. W., A. Streckeisen, B. Zanettin, M. Le Bas, B. Bonin, and P. Bateman (2005). "Igneous rocks: a classification and glossary of terms: recommendations of the International Union of Geological Sciences". Subcommision on the Systematics of Igneous Rocks. Ed. by R. W. Le Maitre. Cambridge University Press.

Leake, B. E., A. R. Woolley, C. E. S. Arps, W. D. Birch, M. C. Gilbert, J. D. Grice, F. C. Hawthorne, A. Kato, H. J. Kisch, V. G. Krivovichev, K. Linthout, J. Laird, J. Mandarino, W. V. Maresch, E. H. Nickel, N. M. S. Rock, J. C. Schumacher, D. C. Smith, N. C. N. Stephenson, L. Ungaretti, E. J. W. Whittaker, and G. Youzhi (1997). "Nomenclature of Amphiboles Report of the Subcommittee on Amphiboles of the International Mineralogical Association Commission on New Minerals and Mineral Names". Mineralogical Magazine 61(405), pp. 295-310. Dor: 10.1180/ minmag. 1997.061.405.13.

McKenzie, D. and M. J. Bickle (1988). "The Volume and Composition of Melt Generated by Extension of the Lithosphere". Journal of Petrology 29(3), pp. 625-679. ISSN: 1460-2415. DOI: 10.1093/petrology/29.3.625.

Pankhurst, M. J., K. J. Dobson, D. J. Morgan, S. C. Loughlin, T. Thordarson, P. D. Lee, and L. Courtois (2014). "Monitoring the Magmas Fuelling Volcanic Eruptions in Near-real-time Using X-ray Microcomputed Tomography". Journal of Petrology 55(3), pp. 671-684. IssN: 1460-2415. DOI: $10.1093 /$ petrology/egto79.

Pankhurst, M. J., D. J. Morgan, T. Thordarson, and S. C. Loughlin (2018). "Magmatic crystal records in time, space, and process, causatively linked with volcanic unrest". Earth and Planetary Science Letters 493, pp. 231-241. IssN: 0012-821X. DOI: $10.1016 / \mathrm{j}$.epsl. 2018.04 .025$.

Pirrie, D. and G. K. Rollinson (2011). "Unlocking the applications of automated mineral analysis". Geology 
Today 27(6), pp. 226-235. Issn: 0266-6979. DOI: 10 . 1111/j.1365-2451.2011.00818.x.

Re, G., R. A. Corsaro, C. D’Oriano, and M. Pompilio (2021). "Petrological monitoring of active volcanoes: A review of existing procedures to achieve best practices and operative protocols during eruptions". Journal of Volcanology and Geothermal Research 419, p. 107365. ISSN: 0377-0273. DOI: $10.1016 / \mathrm{j}$. jvolgeores.2021.107365.

Rodriguez-Losada, J. A., A. Eff-Darwich, L. E. Hernandez, R. Viñas, N. Pérez, P. Hernandez, G. Melián, J. Martinez-Frías, M. C. Romero-Ruiz, and J. J. CoelloBravo (2015). "Petrological and geochemical Highlights in the floating fragments of the October 2011 submarine eruption offshore El Hierro (Canary Islands): Relevance of submarine hydrothermal processes". Journal of African Earth Sciences 102, pp. 4149. IssN: 1464-343X. DoI: $10.1016 / \mathrm{j}$. jafrearsci . 2014.11 .005$.

Rollinson, G. K., J. C. Ø. Andersen, R. J. Stickland, M. Boni, and R. Fairhurst (2011). "Characterisation of non-sulphide zinc deposits using QEMSCAN®". Minerals Engineering 24(8), pp. 778-787. IssN: 08926875. DoI: $10.1016 / \mathrm{j}$. mineng . 2011.02 .004 .

Romero Ruiz, M. d. C. (1990). "Las manifestaciones volcánicas históricas del Archipiélago Canario". PhD thesis. Universidad de La Laguna, Tenerife, Canary Islands, Spain.

Turner, S., K. Hoernle, F. Hauff, T. S. Johansen, A. Klügel, T. Kokfelt, and C. Lundstrom (2015). " ${ }^{238} \mathrm{U}-{ }^{230} \mathrm{Th}-{ }^{226} \mathrm{Ra}$ Disequilibria Constraints on the Magmatic Evolution of the Cumbre Vieja Volcanics on La Palma, Canary Islands". Journal of Petrology 56(10), pp. 1999-2024. IssN: 1460-2415. DOI: 10 . 1093/petrology/egv061.

White, J. D. L. and H.-U. Schmincke (1999). "Phreatomagmatic eruptive and depositional processes during the 1949 eruption on La Palma (Canary Islands)". Journal of Volcanology and Geothermal Research 94(1-4), pp. 283-304. DOI: $10.1016 / \mathrm{s} 0377-0273(99) 00108-0$. 